ISSN: $1130-3743$

\title{
TRABALHO, ESCOLA E BRINCADEIRA. A UTOPIA DE PINÓQUIO
}

\author{
Work, school and fun. The utopia of Pinocchio
}

\section{Travail, école et jeu. L’utopie de Pinocchio}

Joaquim MACHADO DE ARAújO* y Alberto Filipe ARAÚJO**

* Universidade Católica Portuguesa. Faculdade de Educação e Psicologia

(Campus da Foz). Rua Diogo Botelho, 1327. 4169-005 Porto-Portugal.

Correo-e: jomachado@porto.ucp.pt

** Universidade do Minho. Instituto de Educação. Campus de Gualtar. 4710-057

Braga-Portugal. Correo-e: afAraújo@ie.uminho.pt

Fecha de recepción: enero de 2012

Fecha de aceptación definitiva: abril de 2012

Biblid [(1130-3743) 24, 1-2012, 41-55]

\section{RESUMEN}

Las Aventuras de Pinocho relatan la Historia de un Muñeco que se transforma de un estado de naturaleza para un estado de cultura y se desarrolla moralmente de la heteronomía para la autonomía. En el curso de su formación, experimenta la desilusión del milagro de la multiplicación del dinero sin trabajar y de la utopía de una tierra donde solo existe el juego -sueño de cualquier niño-, lo que lo reduce al estado animal. La metáfora del burro que se aplica al niño que fracasa en la escuela es adaptada a la situación del muñeco animado, evidenciando una perspectiva cultural sobre las consecuencias del prolongamiento temporal del estado de naturaleza y dejando a quien se escapó de la escuela, primero la ociosidad y más tarde el trabajo duro y el autoaprendizaje.

Palabras clave: escuela, trabajo, juego, heteronomía, autonomía. 
SUMMARY

The Adventures of Pinocchio tell the Story of a Toy in a transition from the state of nature to the state of culture, of someone who develops himself morally from heteronomy to autonomy. In his development, he experiences the disenchantment of the miracle of the money multiplication without work and the utopia of a fun land, the dream of any child. He reduces himself to the condition of an animal. The metaphor of the monkey to which he is faced when he is not succeeded in school is brought to the life of the animated toy. The cultural perspective on the consequences of the delay in maintaining a state of nature becomes a reality to the one who has run away from school at first. Then the one who has idleness has a goal turns to be a serious concern. At least the one who has work and self-directed learning as main aims is a relevant turning point to this tale.

Key words: school, work, fun, heteronomy, autonomy.

\section{SOMMAIRE}

Les Aventures de Pinocchio racontent l'histoire d'un petit pantin de bois qui passe de l'état de nature à l'état de culture dans lequel il développe son caractère moral de l'hétéronomie pour l'autonomie. Au cours de sa formation, il éprouve la désillusion du miracle de la multiplication de l'argent sans travail et de l'utopie d'un monde plein de jouissance et de frivolité, le rêve de tout enfant, mais qui se termine dans le cauchemar, puisque Pinnochio se transforme en âne. La métaphore de l'âne, qui symbolise parfaitement l'échec scolaire de l'enfant, est vécue dramatiquement par le petit pantin vivant, tout en rendant-compte d'une perspective culturelle sur les conséquences du prolongement temporaire de l'état de la nature et délaissant à celui qui quitte l'école, premièrement, l'oisiveté et, finalement, la corvée et l'autoapprentissage.

Mots clés: école, travail, jeu, hétéronomie, autonomie.

\section{INTRODUÇÃO}

A importância da imaginação na educação ocupou o pensamento de John Passmore (1980) que assinala a dificuldade da racionalidade educativa aceitar a intromissão da imaginação, porquanto ela é encarada como uma emissária do «irracional" e, portanto, uma anomalia para a construção de uma aprendizagem racional mediada por componentes curriculares que obedecem a uma lógica de inspiração positivista e iconoclasta, dualista e do terceiro excluído (Egan, 1992). Passmore e Egan colocam a ênfase na "capacidade de imaginar" (imaginativeness), que é sinónimo de "ser imaginativo" e corresponde à "mente a trabalhar" livremente, opondo-se à fantasia (fancy), "mente a brincar", "Sonhar acordado". Nesta perspetiva Montessori (1971) e Dewey (1975) incitam a capacidade de imaginar, o exercício da imaginação, o trabalho da mente, pondo este exercício ao serviço 
das necessidades de aprendizagem. Wunenburger (1993), por sua vez, realça que a imaginação carece de ser cultivada de acordo com uma "Bildung", ou seja, com um modelo axiológico de humanidade.

A literatura para crianças e jovens oferece um conjunto temático variado com forte ligação quer à educação, quer à imaginação, cabendo muitos dos seus temas e obras à categoria do romance de formação (Bildung). Assim, por exemplo, encontramos o tema da iniciação, de forte pendor formativo, nos contos de Charles Perrault, de Hans Christian Andersen, dos Irmãos Grimm e de Lewis Carroll. Encontramo-lo também n'As Aventuras de Pinóquio de Carlo Collodi, onde podemos salientar a passagem do herói pelo ventre do tubarão, o que corresponde a um "segundo nascimento" (Araújo \& Araújo, 2010) e consequentemente, a uma metamorfose da sua personalidade mais profunda, a ponto de "assumir-se como um eu" (Meirieu, 1996, 31). A Filosofia da Educação acolhe a necessidade da iniciação, enquanto função equilibradora e de recondução à profundidade daquilo que cada um é, podendo ajudar o ser humano a romper com as máscaras sobre as quais cada um se esconde aos outros e a si mesmo (Araújo \& Araújo, 2010, 58).

O nosso estudo visa ilustrar através d'As Aventuras de Pinóquio o papel formativo da imaginação mediada pelo tema da iniciação e, consequentemente, a relação da literatura infantil com a educação. Optamos por uma metodologia que segue os procedimentos da hermenêutica de Paul Ricoeur (1969 e 1987) e faz da interpretação, que no nosso caso é de cariz mítico-simbólico, a sua pedra-angular. Esta atitude interpretativa incorpora o contributo da tradição e seus textos de referência, na base dos quais procura compreender os "enjeux" da problemática tratada para, em seguida, lançar o hermeneuta no caminho necessariamente conflitual de uma interpretação que tem como sua principal missão acrescentar mais sentido à tradição, residindo aqui o nosso contributo inovador ao domínio da Teoria da Educação, por via da filosofia do imaginário educacional (Araújo \& Araújo, 2009), nomeadamente a abordagem utópica no interior do percurso formativo da personagem, até hoje não privilegiada nos estudos sobre As Aventuras de Pinóquio.

No conto de Carlo Collodi, constatamos que, com o pedaço de madeira com vida que Mestre António lhe dá, Gepeto pretende "construir um belo boneco de madeira; mas um boneco maravilhoso, que saiba dançar, fazer esgrima e dar saltos mortais", para com ele correr mundo e "granjear um naco de pão e um copo de vinho" (Collodi, 2004, 10).

Porém, depois de "criado", o boneco revela-se bem travesso e insubmisso. Se já fora difícil dar-lhe forma física, mais difícil é modelá-lo sob o ponto de vista moral. Os actos de Pinóquio são orientados pela satisfação das suas necessidades básicas -como comer, aquecer-se, dormir. Ele é um boneco que sempre promete obedecer, mas que sistematicamente se deixa guiar pela natureza, acabando por rejeitar a escola e o trabalho, que são do domínio da cultura.

As Aventuras de Pinóquio relatam a História de um Boneco que passa do estado de natureza ao estado de cultura e se desenvolve moralmente da heteronomia para a autonomia. E, nesse percurso de formação, experiencia a quimera dos 
milagres da árvore das patacas e a utopia de uma terra só de brincadeira, o sonho de qualquer criança, cujas consequências conduzem, na perspectiva do autor da obra, a um processo de animalização, traduzido em estado asinino.

A metáfora do burro que se colocou à criança que fracassa na escola é trazida para a vida do boneco animado, dando conta de uma perspectiva cultural sobre as consequências do prolongamento temporal do estado de natureza, e é o mote para a transformação de Pinóquio que, tornando-se autor dos seus actos, deixa de ser boneco ou fantoche, conduzido por outros, e passa a ser um "rapaz" como deve ser.

\section{PINÓQUiO PROMETE IR À ESCOLA E APRENDER UM OFÍCIO}

Depois de uma das suas traquinices, Pinóquio faz o que fazem todos os miúdos que querem obter alguma coisa. Chorando, ele promete a Gepeto exactamente o que este pretende dele: "-Prometo-te [...] que a partir de hoje vou ser bonzinho. [...] Prometo-te que irei à escola, que estudarei e que serei bom aluno. [...] Prometo-te, pai, que aprenderei um ofício e que hei-de ser o teu consolo e o teu amparo na velhice" (Collodi, 2004, 33). E, obtido o que pretendia (a reparação da madeira dos seus pés, que queimara na lareira) manifesta a vontade de cumprir o prometido: "-Para te compensar de tudo o que fizeste por mim [...], quero ir já para a escola" (ibid., 34).

Porém, a frequência da escola exige despesas e Gepeto é pobre. O pai que mande o filho para a escola tem que providenciar-lhe roupa adequada e o material escolar. Para vestuário, recorre aos materiais disponíveis e veste Pinóquio como autêntico boneco: "Gepeto, que era pobre e não tinha no bolso nem um cêntimo, fez-lhe um fato de papel às flores, um par de sapatos de casca de árvore e um chapelinho de miolo de pão" (ibid., 35). Mas, como adverte o filho, falta o mais importante para ir a escola, a cartilha e essa o pai não a podia fazer, nem tinha dinheiro para a comprar na livraria. Acaba, por isso, por vender o seu velho casaco de fusão, mesmo que "todo passajado e remendado", que bem falta lhe fazia nesse inverno nevoso, e com o dinheiro apurado compra a cartilha para o filhote.

Pinóquio está reconhecido, salta ao pescoço do pai e cobre-o de beijos. Quando acaba de nevar, põe a cartilha debaixo dos braços, mete os pés a caminho e vai entusiasmado para a escola, aflorando à sua cabeça "mil pensamentos e mil castelos no ar, qual deles mais belo do que o outro" e, "falando sozinho, dizia: Hoje na escola quero aprender logo a ler, e amanhã aprenderei a escrever, e no dia seguinte a fazer os números. Depois, com a minha inteligência ganharei muito dinheiro, e com as primeiras moedas que me caírem no bolso quero mandar fazer um belo casaco de lã para o meu pai» (ibid., p. 37). 


\section{NÃo É DA NATUREZA DE PINÓQUio IR À ESCOLA OU APRENDER UM OFÍCIO}

A escola não é da ordem da natureza, mas, sim, uma organização social para a educação formal, realizada através de uma actividade especificamente formalizada e utilizando profissionais especializados como agentes educativos, exercida durante um período etário determinado e numa relação directa e prolongada entre educadores e educando (Pires, Fernandes \& Formosinho, 1998, 63-70). Assim, logo que Pinóquio ouve bem longe uma música de pífaros e toques de tambor e tendo que optar entre estes e a escola, a escolha tornou-se óbvia e a resolução foi rápida: "Hoje vou ouvir os pífaros e amanhã vou à escola: para ir à escola estou sempre a tempo -disse por fim aquele maroto, encolhendo os ombros" (Collodi, 2004, 38).

Pinóquio cede à sedução dos pífaros e da ambiência que a música proporciona. Adiando o cumprimento da obrigação, acaba por vender a cartilha nova (que tanto custara ao pai) para fazer dinheiro e pagar a entrada para o teatro de fantoches. Nisto reside a "maroteira" de Pinóquio: deixar de ir à escola e vender num abrir e fechar de olhos a cartilha que o pai comprara, despojando-se do próprio agasalho! Mas, o impulso dos seus actos ganha em compreensão quando se fica a saber que os fantoches o reconhecem como um deles, como "O seu irmão", e o recebem com muita alegria e amizade fraternal:

É impossível imaginar os abraços, os apertos de pescoço, os beliscões de amizade e as cabeçadas de verdadeira e sincera fraternidade que Pinóquio recebeu, no meio de enorme confusão, dos actores e actrizes daquela companhia dramático-vegetal (ibid., 42).

$\mathrm{Na}$ verdade, Pinóquio, o boneco, tem a sua leitura do mundo das crianças: todas as crianças são mandadas para a escola e a bem ou a mal têm de estudar. E, face à obrigação e ao esforço que o esperam, reage como criança não motivada para aprender e ainda não socializada na importância da escola para a inserção na vida económico-social: "Não tenho nem um bocadinho de vontade de estudar, e divirto-me mais a correr atrás das borboletas e a subir às árvores para tirar os passarinhos dos ninhos" (ibid., 20).

A natureza de Pinóquio tão-pouco o impele ao trabalho, a alternativa honesta para quem não agrada a escola: "Entre todos os ofícios do mundo, há só um de que eu gosto. [...] O de comer, beber, dormir, divertir-me e levar a vida de vadio de manhã à noite" (ibid., 21).

Trata-se, na verdade, da expectativa de um boneco de madeira, de alguém que pensa com "uma cabeça de pau" (ibid., 21) e, por isso, ainda é capaz de acreditar na quimera da "árvore das patacas".

\section{Quimera do CAMPo dos Milagres e PROMEsSa de MudanÇA DE VIDA}

Tendo recebido do dono dos fantoches cinco moedas de ouro para as levar a seu pai, Pinóquio acaba por deixar-se seduzir pela ideia de as multiplicar, 
precisamente na Terra dos Tolos, onde haveria um campo abençoado, o Campo dos Milagres. Nele se podia fazer um buraco, meter uma moeda, cobrir o buraco com terra, regá-lo com água da fonte e deitar-lhe por cima uma mão cheia de sal que, durante a noite, enquanto se dorme descansadamente, a moeda germinaria e floresceria e tornar-se-ia "uma bela árvore carregada de tantas moedas de ouro quantos os grãos de trigo que pode ter uma boa espiga no mês de Junho" (ibid., 53).

$\mathrm{Na}$ verdade, Pinóquio comporta-se como "um refinado malandro [...], um maroto, um preguiçoso, um vadio" (ibid., 70) e não consegue ver que está sendo ludibriado, mesmo passando antes pela cidade de Caça-Néscios e vendo que aí tudo era expressão do contrário do que procurava:

Pinóquio viu que todas as ruas estavam cheias de cães pelados que bocejavam com fome, de ovelhas tosquiadas que tremiam de frio, de galinhas sem crista nem barbilhões que pediam a esmola de um grão de milho, de grandes borboletas que não podiam voar porque tinham vendido as suas belíssimas asas coloridas, de pavões sem cauda que tinham vergonha de serem vistos, e de faisões que corriam dum lado para o outro em silêncio, saudosos das suas penas cintilantes de ouro e prata perdidas para sempre (ibid., 82).

Enfim, a dois passos do Campo dos Milagres, a natureza estava depauperada, povoada por "uma multidão de mendigos e de pobres envergonhados", por entre a qual "passavam de vez em quando algumas carruagens senhoris que transportavam alguma raposa ou alguma pega gatuna, ou então alguma ave de rapina” (ibid., 82). Pinóquio viu, mas não compreendeu, porque lhe faltava a grelha de leitura necessária à compreensão do milagre do Campo dos Milagres e saber em que consiste o milagre, como acontece e a quem beneficia.

À ilusão de uma boa colheita e do enriquecimento sem se cansar, segue-se, por conseguinte, a tomada de consciência do ludíbrio e do roubo de que fora vítima através da gargalhada do papagaio que, tendo sido vítima da mesma quimera e já se convencera de que "para juntar algum dinheiro honestamente é preciso saber ganhá-lo, quer com o trabalho das nossas mãos quer com a inteligência da nossa cabeça", se ria agora dos "néscios que acreditam em todos os disparates e se deixam enganar por quem é mais esperto do que eles" (ibid., 86). Nisto reside, com efeito, a tolice, a necedade, a falta de tino de Pinóquio e, por ele, o sonho de ganhar muito dinheiro sem grande trabalho redunda em total desilusão e perda total do pouco dinheiro que devia entregar a Gepeto.

Desesperado, Pinóquio queixa-se ao juiz que se enterneceu e comoveu com a descrição do caso, mas o mandou prender por se ter deixado roubar, só saindo da prisão quando, querendo aproveitar uma amnistia que libertava todos os malandros, reivindicou este estatuto para si mesmo: "Eu também sou um malandro" (ibid., 88).

Este episódio do Campo dos Milagres e a prisão que se lhe seguiu levam Pinóquio à constatação de que todas as desgraças que lhe aconteceram «são bem 
merecidas, porque eu sou um boneco teimoso e casmurro... e quero fazer sempre tudo à minha maneira, sem dar ouvidos àqueles que me querem bem e que têm mil vezes mais juízo do que eu..." (ibid., 89).

Este acto de contrição pede uma promessa de conversão. E Pinóquio promete a si mesmo:

Mas a partir de agora faço o propósito de mudar de vida e de me tornar um rapaz obediente e como deve ser. Até porque já vi bem que os miúdos que são desobedientes ficam sempre a perder e não acertam uma... (ibid., 89).

\section{PinÓQUiO VÊ-SE NA NECESSIDADE DE TRABALHAR PARA COMER}

Depois de várias peripécias, Pinóquio chega a uma ilha, experiencia o isolamento e acha a Terra das Abelhas Laboriosas, onde "todos trabalhavam, todos tinham alguma coisa para fazer", onde "não se encontrava um ocioso ou um vadio, nem mesmo procurando com uma lanterna" (ibid., 109).

Obviamente que Pinóquio, o boneco "preguiçoso", não se reconhece esta povoação como a sua: "Esta terra não foi feita para mim. Eu não nasci para trabalhar" (p. 110). Mas, como a vontade de comer era mais forte que a não vontade de trabalhar, tenta o modo alternativo de poder comer alguma coisa e pede dinheiro emprestado, que receberia em quadruplicado ou em quintuplicado se em contrapartida prestasse o trabalho que lhe era pedido -ajudar a puxar uma carroça do carvoeiro, transportar argamassa do pedreiro, por exemplo. Porém, tudo rejeitou até que acabou por aceitar ajudar uma mulher a levar até casa uma bilha de água, mas depois de esta lhe prometer, para além da comida, uma boa guloseima.

Foi esta boa mulher, na verdade a sua Fadazinha, a Fada dos cabelos azulturquesa agora tornada mulher, que fez sentir em Pinóquio o desejo de "crescer", desejo este que não estava ao seu alcance por ele ser "boneco": "Os bonecos nunca crescem. Nascem bonecos, crescem bonecos e bonecos morrem" (ibid., 116). Ao desejo de vir a ser um "homem", Pinóquio tem de acrescentar o merecimento de o ser, habituando-se a ser um "rapazinho bem-comportado" (ibid., 116). Enquanto os rapazinhos bem-comportados são obedientes, têm dedicação ao estudo e ao trabalho, dizem sempre a verdade e gostam de ir à escola, Pinóquio, pelo contrário, nunca obedece, leva vida de mandrião e de vadio durante o ano inteiro, diz sempre mentiras e a escola provoca-lhe dores de barriga.

$\mathrm{Na}$ verdade, segundo a Fada, Pinóquio é travesso e não prima pela "boa educação", mas tem bom coração e, por isso, justifica a esperança dela de que ele "entre no bom caminho" e, querendo ele, transformar-se em rapaz bem-comportado e "ser o consolo do pai", promete obedecer-lhe e fazer sempre o que esta verdadeira "mãe" lhe disser. O entusiasmo de Pinóquio esbate-se, porém, quando a fada lhe determina que no dia seguinte começaria a ir à escola e que, depois, será a vez de escolher uma arte ou um ofício a seu gosto (ibid., 117). Para o boneco que quer ser "homem" e, para isso, tem de ser "rapazinho bem-comportado", "para ir para a 
escola já lhe parece um pouco tarde", e não pretende aprender nenhuma arte nem nenhum ofício, simplesmente porque acha que "trabalhar é cansativo". Por sua vez, para a sua "mãe", nunca é tarde para uma pessoa se instruir e para aprender e, tal como já lhe dissera o Grilo-Falante (ibid., 20), quem foge ao trabalho e se afunda na ociosidade acaba quase sempre na prisão ou no hospital: "Pois fica sabendo que o homem, quer nasça rico quer nasça pobre, tem a obrigação de fazer alguma coisa neste mundo, de ter uma ocupação, de trabalhar. Ai daquele que se entrega ao ócio! O ócio é uma doença terrível que é preciso curar logo, desde miúdo; senão, quando somos crescidos já não temos cura" (ibid., 118).

\section{PinÓQUio VAi À ESCOLA E É BOM ESCOLAR}

As palavras da mãe fada bem "tocaram o coração de Pinóquio" e o levaram a assegurar: "-Eu vou estudar, vou trabalhar, vou fazer tudo o que me disseres, porque afinal já estou farto da vida de boneco e quero transformar-me num rapaz custe o que custar» (ibid., 118). Mas entre o dizer e o cumprir, a distância é elástica.

Dependia, de facto, de Pinóquio o cumprimento da promessa à mãe fada. E, no primeiro dia, aí vai ele à escola (a escola municipal), suporta com desenvoltura as marotices que os colegas lhe aprontam e, quando a paciência lhe começa a faltar, exige-lhes respeito - "Eu respeito os outros e quero ser respeitado também!" (ibid., 119) - mas foi à custa dos seus pontapés e cotoveladas que "conquistou imediatamente a estima e a simpatia de todos os rapazes da escola, e todos lhe faziam festas e lhe queriam bem no fundo do coração" (ibid., 120). No que respeita ao comportamento em aula, "até o professor o gabava, pois via-o atento, estudioso, inteligente, sempre o primeiro a entrar na escola e sempre o último a pôr-se em pé quando as aulas acabavam" (ibid., 120).

Se Pinóquio primava por todas as qualidades que um escolar deve ter, a escola não seria o melhor dos mundos para todas as crianças, porquanto a abrangência da sua convivência escolar incluía "muitos malandros bem conhecidos pela pouca vontade de estudar e de se portarem bem", como observava o professor. Enfim, "más companhias" que, a qualquer momento, acabariam por o "fazer perder o amor ao estudo", como advertia repetidas vezes a boa Fada.

E a oportunidade não se fez esperar, suscitada pela curiosidade em ver, ali tão perto no mar, um presumível Tubarão enorme e por todos os argumentos aduzidos pelos colegas para justificarem a irrelevância da falta à escola naquele dia, quando, de facto, o principal objectivo era fazer com que ele "falhasse" na pontualidade e na assiduidade, assim como queriam que ele falhasse no estudo, porquanto o sucesso de Pinóquio evidenciava a "má figura" dos colegas e feria o amor-próprio de quem tinha três grandes inimigos: a escola, as aulas, o professor (ibid., 124).

Embora, depressa Pinóquio tivesse razões para se arrepender e de voltar a prometer à Fada que deixaria de ser um boneco e passaria a ser um rapaz, a verdade é que é mais fácil prometer que cumprir e, no caso da falta à escola, o que custa é a primeira vez. 


\section{PinÓQuio VAi Para a Terra da Brincadeira}

De entre os colegas de escola, Palito é amigo predilecto de Pinóquio, é aquele que comunga da mesma natureza (a madeira), mas é mais frágil. Aliás, Palito é «O miúdo mais preguiçoso e o mais travesso da escola toda" (ibid., 146). E é ele que "empurra" Pinóquio para o que seria a "Terra Prometida" dos meninos em idade escolar, a Terra da Brincadeira:

Lá não há escolas, não há professores, não existem livros. Naquela bendita terra nunca se estuda. Ao sábado não há escola, e as semanas lá compõem-se de seis sábados e um domingo. Imagina tu que as férias de Verão começam no primeiro dia de Janeiro e terminam no último de Dezembro. [...] [Lá, os dias] Passam-se a brincar e a divertir-se de manhã à noite. Quando é noite vai-se para a cama, e na manhã seguinte começa-se a brincar outra vez (ibid., 147).

São estas características da Terra da Brincadeira que atraem Pinóquio, que lhe fazem "crescer água na boca", que não lhe permitem tornar decisivas as suas respostas negativas ao convite do amigo, a retardar a volta para casa: "É uma vida que eu também faria de boa vontade!» (ibid., 147); "Que beleza de terra! Eu nunca lá estive mas imagino como é!» (ibid., 149); "Que beleza de terra!" (ibid., 149); "Que beleza de terra!... que beleza de terra!... Oh! Mas que beleza de terra!" (ibid., 150).

O encanto da Terra da Brincadeira vem-lhe da sua característica própria das utopias: "Um dos processos utópicos mais fáceis e mais elementares, que joga frequentemente quase só nas utopias mais primitivas, e que de facto nunca falta, é a inversão pura e simples da realidade. É evidentemente a experiência mental mais fácil» (Ruyer, 1988, 49). O sucesso da apresentação do "novo" mundo como a cópia invertida do mundo daquele que o utopista aspira a dele sair não advém, contudo, apenas da sua simplicidade, mas também porque "corresponde ao ressentimento oculto sob o desejo de poder do utopista, e ao negativismo do intelectual e do especulativo. [...] Face às imperfeições da realidade, a reflexão menos cansativa para a inteligência, e aquela que consola melhor o sentimento, é dizer-se que tudo iria melhor se se pusesse tudo ao contrário" (Ruyer, 1988, 50).

Outra característica é o do eudemonismo colectivo: "Vem daí connosco e viveremos todos felizes!», como apela Palito e as vozes dos passageiros da carruagem que os conduz para utopia (Collodi, 2004, 152-153). Na verdade, a moral do utopista "apela ao que de mais elevado há na natureza humana", sem apelar a uma moral heróica ou a uma moral religiosa de salvação (mais própria dos profetas, dos fanáticos, dos apaixonados), e sonha apenas com a felicidade: "Um mundo utópico, com instituições perfeitas, não tem necessidade nem do heroísmo na sua moral, nem do salvador na sua religião" (Ruyer, 1988, 52).

A terceira característica da Terra da Brincadeira é a de que nela não há limitação da liberdade de brincar: "Vamos para uma terra onde ninguém nos impedirá de brincar de manhã à noite». Este é, de facto, o argumento mais convincente para 
Pinóquio: "Façam lugar para mim; também quero ir" (Collodi, 2004, 153). Ele faz lembrar a única cláusula que havia na regra que Gargântua estabelecera na Abadia de Theleme: Fais ce que vous voudra, "Faz o que quiseres". Com a certeza de que cada um apenas dirá: "Joguemos" e todos jogam; ou "Brinquemos" e todos brincam (Rabelais, 1987, 215).

A Terra da Brincadeira insere-se, assim, mais naquelas utopias que, ao contrário das utopias minuciosas, quase que dispensam as instituições (Ruyer, 1988, 76) ou, no mínimo, faz dos jogos, dos divertimentos e das brincadeiras as próprias instituições utópicas. Na verdade, o utopista é "institucionalista", no sentido em que ele faz da instituição uma causa e não um efeito, ele crê nelas e sacrifica-lhes a natureza humana: ele esforça-se por adaptar o homem às instituições e não as instituições ao homem (Ruyer, 1988, 79). E, neste caso, o único beneficiário era o homenzinho da carruagem, aquele "mostrengo horrível que tinha um ar tão doce e suave", corria o mundo a recolher, com promessas e denguices, os rapazes mandriões que detestavam os livros e a escola, levava-os para a Terra da Brincadeira para os transformar em burrinhos, apoderar-se deles e ir vendê-los pelas feiras e mercados. "E, assim, em poucos anos ganhara muito dinheiro e tornara-se milionário" (Collodi, 2004, 170).

Por último, chegar a utopia é "renascer" para uma nova vida, é iniciar uma vida nova, tal como o dia renasce e "de manhã ao alvorecer chegaram felizes à Terra da Brincadeira" (ibid., 155) Pinóquio, Palito e todos os rapazes viajantes para utopia: "Mal acabaram de pôr o pé na cidade meteram-se logo no meio da balbúrdia, e em poucos minutos, como é fácil de imaginar, tornaram-se amigos de todos. Ninguém podia estar mais feliz e contente do que eles" (ibid., 156). Era a felicidade total: "Entre contínuos folguedos e divertimentos vários, as horas, os dias e as semanas passavam sem se dar por isso" ( ibid., 156). E, assim, durante cinco meses foi "aquela maravilha de brincarem e se divertirem os dias inteiros, sem verem à sua frente nem um livro, nem uma escola, nem o professor... nem o pai, nem a mãe... nem qualquer um que pusesse entraves ao contínuo folgar e à felicidade total».

\section{PinÓQUiO TRANSFORMA-SE EM BURRO}

Não sabia, porém, Pinóquio que "O sofisma das utopias é aplicar a um puro sistema de instituições o que não é verdadeiro senão na ordem moral: Todas as virtudes parecem virtudes-chave, porque na realidade elas se requerem mutuamente. Mas não há Instituição-Sésamo perante a qual todas as dificuldades em todos os domínios se esvaiam" (Ruyer, 1988, 70).

Sabia-o, porém, o "burrinho" que puxava a carruagem que assegura o transporte para a Terra da Brincadeira. Primeiro, atira para o ar Pinóquio, o "pobre boneco", e, depois, para o meio da estrada e, finalmente, vai-o avisando: "Pobre pateta, quiseste fazer o que te apeteceu mas hás-de arrepender-te" (Collodi, 2004, 154); "-Mete isto na cabeça, palerma! Os miúdos que deixam de estudar e voltam as 
costas aos livros, às escolas e aos professores para se entregarem completamente à brincadeira e ao divertimento, acabam sempre por ter um triste fim..." (ibid., 155).

Pinóquio viria a sabê-lo também quando se descobriu "burro", tal como se descobriu Palito e cada um dos que ousou mergulhar completamente na Terra da Brincadeira. O "burrinho" bem confessara e advertira: "-Eu aprendi isso à minha custa... e posso dizer-to. Chegará o dia em que tu também tu hás-de chorar, como eu hoje choro... mas nessa altura já será tarde» (ibid., 155).

Mas esse é o destino e, por isso, de nada valeria chorar: "Está escrito nos decretos da sabedoria que todos os miúdos mandriões que aborrecem os livros, as escolas e os professores e passam os dias na brincadeira e em jogos e em divertimentos, mais cedo ou mais tarde acabam por se transformar em burrinhos", como the diz a Marmotinha (ibid., 160 e 162). Aliás, quando Pinóquio e Palito se descobrem ambos com sintomas físicos asininos, "em vez de ficarem mortificados e desgostosos começaram a fazer macaquices com as orelhas enormes e, depois de mil tropelias, acabaram por dar umas boas gargalhadas" (ibid., 164 e 166). Tinham eles iniciado já o processo avançado de animalização, depressa ficando com corpo de burro: "Inclinaram-se os dois para o chão e, apoiando-se nos pés e nas mãos, começaram a dar voltas e a correr pela casa. E enquanto corriam os braços transformaram-se em patas, os rostos alongaram-se e transformaram-se em focinhos, e as costas cobriram-se de uma pelagem acinzentada com manchas pretas" (ibid., 166). Mas foi quando sentiram a cauda a nascer, que ficaram "vencidos pela vergonha e pelo desgosto, começaram a chorar e lamentar-se do seu destino" (ibid., 166), mas agora com zurros asininos em vez de gemidos e lamentos humanos.

\section{A natureza animal de PinÓQuio É domada}

$\mathrm{Na}$ perspectiva dominante da narrativa de Carlo Collodi, aqueles rapazes mandriões que detestavam os livros e a escola e se deixavam transportar para a Terra da Brincadeira, para ali passarem todo o tempo em jogos, folias e divertimentos acabavam por se transformar em "burrinhos" e serem vendidos para viverem e trabalharem como "burros", levarem "uma vida muito dura e de maus tratos" (ibid., 170).

Assim, Pinóquio é comprado pelo director de uma companhia de palhaços e saltimbancos "para o amestrar e ensinar a saltar e a dançar juntamente com outros animais da companhia". "A bem ou a mal" Pinóquio teve de aprender "a saltar ao arco, a furar os barris de folha com a cabeça e a dançar a valsa e a polca em pé nas patas traseiras". Ele foi domado e treinado à custa de muitas lições e muitas chicotadas e alimentado a feno e palha, pondo à prova a sua "paciência de burro" (ibid., 170, 171 e 174): "Observai quanta selvajaria transpira dos seus olhos, pelo que tendo-se revelado vãos todos os meios usados para o adaptar ao modo de viver dos quadrúpedes civilizados, tive de recorrer à linguagem amável do chicote» (ibid., 176). 
Pinóquio tornou-se o burro obediente às ordens do domador e ao estalo do chicote. Para sair dessa vida de burro amestrado, valeu-lhe o ter ficado coxo - "coxo para toda a vida" (ibid., 178) - e ter sido atirado para a água pelo novo dono com o intuito de o afogar para, depois, com a pele do burro morto fazer um tambor para a banda da sua terra. É, de facto, o banho de água que o faz perder toda a capa de asno que o cobria e voltar à condição inicial de "boneco vivo" de madeira. E vai ser o mar o local para onde foge do novo dono e onde terá lugar o seu renascimento para uma vida nova, a sua transformação em "rapaz bem-comportado".

$\mathrm{Na}$ verdade, a perspectiva dominante da História de um Boneco não é, de modo algum, o embrutecimento de quem abandona a escola, mas a capacidade que os entes humanos têm de se dar um destino. A narrativa de Carlo Collodi enxerta-se na perspectiva moderna de Pico della Mirandola de que o homem é "um grande milagre e um ser animado, sem dúvida digno de ser admirado", porquanto, colocado no meio do mundo, árbitro e soberano artífice de si mesmo, pode plasmar-se e dar-se a forma que escolher para si: "Poderás degenerar até aos seres que são as bestas, poderás regenerar-te até às realidades superiores que são divinas, por decisão do teu ânimo" (1989, 53).

\section{PINÓQUIO TORNA-SE RAPAZ BEM-COMPORTADO, ISTO É, TRABALHA E ESTUDA}

Pinóquio encontra o pai no estômago do Tubarão, o mostrengo horrível, e toma a iniciativa da fuga, comanda as operações, transporte o pai às cavalitas e, com a ajuda do Atum na parte final, chega à margem, ao amanhecer, início de um novo dia e de uma nova vida: Pinóquio oferece o braço a Gepeto e leva-o à procura de "pão" e "tecto", já não dá ouvidos a intrujões como o Gato e a Raposa, reconhece a lição do Grilo-Falante e mostra arrependimento por ter maltratado a vOz da consciência, chora copiosamente pela "morte" da sua querida Fadazinha, aconchega o seu velho pai numa "boa caminha de palha", trabalha como burro (substitui o "burro" Palito acabado de morrer) para garantir o sustento do pai, nas horas livres passou a "fazer canastras e cestos de junco" para fazer face às despesas do dia-a-dia, "construiu sozinho uma elegante carrocinha para levar o pai a passear e apanhar ar nos dias bonitos" e, pasme-se!, ainda encontra energias e tempo para exercitar o ler e o escrever, importantes instrumentos de cultura:

E ao serão exercitava-se a ler e a escrever. Na aldeia vizinha tinha comprado por poucos cêntimos um grande livro a que faltavam o frontispício e o índice, e nele praticava a leitura. Quanto à escrita, usava um pauzinho afiado a servir de caneta; e como não tinha tinteiro nem tinta, molhava-o num frasquinho cheio de sumo de amoras e cerejas (ibid., 204).

Por fim, Pinóquio ainda é capaz de abdicar do pequeno aforro (que seria para comprar roupa e calçado, bens que lhe seriam necessários) para sustentar a sua fada e, naquela noite, esticou o serão e duplicou a produção de canastras, para depois dormir e, dormindo, "ver em sonhos uma Fada muito linda e sorridente" que 
o beija, o aprova e lhe perdoa todas as travessuras feitas até aí como recompensa pelo seu bom coração: "Os meninos que cuidam amorosamente dos pais nas suas desgraças e doenças são sempre merecedores de grande louvor e de muito afecto, mesmo que não possam ser considerados modelos de obediência e de bom comportamento" (ibid., 206). Adverte-lhe a Fada no sonho: "Ganha juízo para o futuro e serás feliz" (ibid., 206).

E é assim, quando deixa que o seu bom coração se revele, que Pinóquio, acordando, "percebeu que já não era um boneco de madeira e que se transformara num rapaz como todos os outros" (ibid., 206). E, maravilha das maravilhas!, "as habituais paredes de palha da cabana" tinham dado lugar a "um belo quartinho mobilado e decorado com uma simplicidade quase elegante", tinha à sua espera "um lindo fato novo, um chapéu novo e um par de botins de pele que lhe assentavam que nem uma luva", nos bolsos do fato encontrou "um pequeno porta-moedas de marfim" com "quatro moedas de ouro novinhas em folha" doados pela fada dos cabelos azul-turquesa e, olhando-se ao espelho,

pareceu-lhe que era outro. Já não via reflectida a imagem habitual do boneco de madeira, mas sim a imagem viva e inteligente de um belo rapazinho de cabelos castanhos e olhos azuis, com um ar de Páscoa alegre e festiva (ibid., 207).

Entrando no quarto do pai, "encontrou o velho Gepeto de perfeita saúde, todo gaiteiro e bem-disposto como noutros tempos, o qual, tendo retomado sem demora a sua profissão de entalhador em madeira, estava precisamente desenhando uma lindíssima moldura ornamentada com folhagens, flores e cabeças de diversos animais" (ibid., 207).

Afinal, a história de Pinóquio que nos é dada a conhecer tem um final de sonho! O próprio Pinóquio duvida se está acordado ou ainda está a sonhar e pretende saber "como se explica toda esta mudança repentina", respondendo-lhe o pai que ela se deve a ele, Pinóquio, que o mérito é dele, "porque quando os meninos eram maus e se tornam bons, têm a virtude de fazer com que até no seio das suas famílias tudo adquira um aspecto novo e sorridente" (ibid., 207).

\section{O DESTINO DA CRIANÇA QUE «FOGE» À ESCOLA}

Decorrido o percurso vivencial de Pinóquio fica o relato da História de um Boneco, o subtítulo da obra de Carlo Collodi, e o seu final feliz, como se de um conto maravilhoso se tratasse, mas lá continuam as consequências sociais do trabalho na horta e do trabalho artesanal, as saídas da época para quem era analfabeto, tinha condições económicas precárias e uma idade desfasada da dos meninos que começavam a aprendizagem dos números e do ABC.

Fica ainda o enaltecimento do esforço individual de alfabetização daquele que, enquanto escolar, virou "desperdício" de uma instituição como a escola (Pauli, 1977) que, nesta obra, é mais sugerida que vivenciada. 
Na economia da obra, Pinóquio é o único responsável do seu "fracasso escolar" por ser ele o "autor" da fuga. O "pai" cumpriu o dever de o "mandar" e, de acordo com os seus parcos recursos, alimentou-o, vestiu-o e deu-lhe a cartilha, embora hoje se pudesse argumentar que falhou no dever de garantir que o "filho" frequentava efectivamente a escola, o que teria evitado o abandono e "fracasso escolar". A escola recebeu-o, o professor "bem avisava" Pinóquio, boneco modelado e aluno modelar, dos perigos das más companhias e dos efeitos nefastos na escolarização. Mas da escola não se sabe nada mais, ficando ainda a sua promessa de um futuro melhor -traduzido em acesso em melhor emprego, melhor remuneração, melhores condições de vida, enfim, a mobilidade social- sugerido pelos pensamentos maravilhosos de Pinóquio no primeiro dia em que se dirige para a escola (Collodi, 2004, 37).

Entretanto, face ao surgimento e à ex-posição do "novo" Pinóquio, o rapaz de bom coração, o "velho Pinóquio de madeira" era agora "um grande boneco apoiado a uma cadeira, com a cabeça virada para um lado, os braços pendurados e as pernas cruzadas e dobradas, que até parecia um milagre segurar-se em pé, (ibid., 208). Ao olhar do "novo" Pinóquio, não deixa de ser "cómico" este boneco que ele mesmo era quando era boneco e enorme é a sua satisfação por deixar de o ser e ter-se tornado um rapaz: "Que cómico que eu era, quando era boneco! E que contente estou agora por me ter transformado num rapazinho como deve ser!" (ibid., 208). Um rapazinho que parece não precisar mais da protecção da Fada dos cabelos azul-turquesa ou da vozinha do Grilo-Falante, por ter interiorizado a cultura que lhe era estranha e ter abandonado o estado de selvagem donde provém.

Por outro lado, podemos perguntar-nos se Carlo Collodi tem uma perspectiva optimista ou pessimista da natureza humana. Com efeito, a constatação da "malvadez" inicial no pedaço de madeira animado modelado em boneco - "Miúdo malvado! E pensar que me esforcei tanto para fazer dele um boneco bem-comportado! Mas tenho aquilo que mereço; devia ter pensado nisso antes" (p. 18)- parece, pelo menos numa primeira leitura, contrariar a perspectiva romântica de Rousseau sobre a natureza humana e fazer subjazer uma concepção pessimista de criança à narrativa do percurso de formação de Pinóquio até ele se tornar numa pessoa moral. Contudo, se considerarmos que estamos a falar da transformação de um pedaço de madeira em ser humano, podemos ver n'As Aventuras de Pinóquio uma ancoragem de Carlo Collodi na primeiro parágrafo do Emílio para contar a História de um Boneco que se torna rapaz em resultado da transformação da natureza pelo homem, mas sobretudo em resultado da construção como ser moralmente autónomo:

Tudo está bem, ao sair das mãos do autor das coisas; tudo degenera entre as mãos do homem: força uma terra a nutrir os produtos de outra, uma árvore a dar frutos de outra; mistura e confunde os climas, os elementos, as estações; mutila o cão, o cavalo, o seu próprio escravo; transtorna tudo, tudo desfigura, gosta da deformidade, dos monstros; não quer nada que seja como o fez a natureza, nem sequer o homem; precisa de o adestrar para si, como um cavalo de manejo; precisa de modelá-lo à sua maneira, como se fosse uma árvore do seu jardim (Rousseau, 1989, 15). 
Contudo, numa leitura mais aprofundada, a perspectiva de Collodi vai para além do debate em torno de uma natureza moralmente preexistente -uma natureza depravada, (deduzida da doutrina do pecado original) ou uma natureza boa (como defende Rousseau) - e aceita o conceito aristotélico da latência, que inclui a predisposição ao desenvolvimento para a bondade moral. No final d'As Aventuras de Pinóquio sobressai a ideia de que Collodi se ancora sobretudo na concepção de que as "criaturas" não nascem boas nem más, mas fazem-se boas ou más. E, neste aspecto, aproxima-se de Kant quando este afirma: "O homem não é por natureza um ser moral; só o será quando eleve a sua razão aos conceitos do dever e da lei» (Kant, 19833, 86). Por isso, também no sentido moral o pedaço de madeira é moldável e o boneco pode "crescer". Por isso também a função social da escola não se restringe à instrução.

\section{REFERENCIAS BIBLIOGRÁFICAS}

ARaújo, Alberto Filipe \& ARAújo, Joaquim Machado de (2009) Imaginário Educacional: figuras e formas. Niterói, Intertexto.

- (2010) Ritual iniciático e imaginário educacional n'As Aventuras de Pinóquio, en AzeVEDO, F. (coord.) Infância, Memória e Imaginário: Ensaios sobre Literatura Infantil e Juvenil. Braga, CIFPEC/Universidade do Minho, 57-84.

Calvino, Italo (2004) Mas, Collodi não existe. Posfácio, en Collodi, C. As Aventuras de Pinóquio. História de um Boneco. S/1, Cavalo de Ferro, 209-215.

Chevalier, Jean \& Gheerbrant, Alain (1994) Dicionário dos simbolos: Mitos, sonhos, costumes, gestos, figuras, cores, números. Lisboa, Teorema.

Cirlot, Juan-Eduardo (2000) Diccionario de simbolos (4. ${ }^{\mathrm{a}}$ ed.). Madrid, Siruela.

Collodi, Carlo (2004) As Aventuras de Pinóquio. História de um Boneco. S/l, Cavalo de Ferro.

DeweY, John (1975) Démocratie et Éducation. Introduction à la philosophie de l'éducation. Paris, Armand Collin.

EGAN, Kieran (1992) Imagination in teaching and learning: ages 8 to 15. London, Routledge. Kant, Immanuel (1983) Pedagogía. Madrid, Akal.

MeIRIEU, Philippe (1998) Frankeinstein Educador. Barcelona, Laertes.

Montessori, Maria (1971) A Mente da Criança (Mente Absorvente). Lisboa, Portugália Editora.

Passmore, John (1980) The Philosophy of teaching. London, Duckworth.

Pauli, J. (1977) O Desperdicio Escolar. Porto, Rés.

Pico della Mirandola, G. (1989) Discurso sobre a Dignidade do Homem. Lisboa, Edições 70.

Pires, E. L.; Fernandes, A. Sousa \& Formosinho, João (1998) A Construção Social da Educação Escolar (2. ${ }^{\text {e }}$ ed.). Porto, Edições ASA.

RabelaIs, F. (1987) Gargântua. Mem Martins, Publicações Europa-América.

Ricoeur, Paul (1969) Le conflit des interprétations: Essai d'herméneutique. Paris, Du Seuil.

- (1987) Teoria da Interpretação. Lisboa, Edições 70.

Rousseau, Jean-Jacques (1989) Emílio, vol. I. Mem Martins, Publicações Europa-América.

RUYER, Raymond (1988) L'utopie et les utopies. Brionne, Gérard Monfort.

WunENBurger, Jean-Jacques (1993) La Bildung ou l'imagination dans l'éducation, en BouveRESSE, R. Éducation et Philosophie: écrits en l'honneur de Olivier Reboul. Paris, Puf, $59-69$ 